\title{
Organizational and social innovation in Non-Profit Organizations performance in the context of an emergent economy
}

\author{
César A. Bernal-Torres ${ }^{1}(\mathbb{D})$, Maricela Isabel Montes-Guerra ${ }^{1}$ (D), \\ Álvaro Turriago-Hoyos ${ }^{1 *}\left(\mathbb{D}\right.$, Hugo Fernando Castro-Silva ${ }^{2}$ \\ ${ }^{1}$ Universidad de La Sabana (Colombia) \\ ${ }^{2}$ Universidad Pedagógica y Tecnológica de Colombia (Colombia) \\ cesar.bernal@unisabana.edu.co,maricela.montes@unisabana.edu.co, ${ }^{*}$ Corresponding author:alvarotuh@unisabana.edu.co, \\ bugofernando.castro@uptc.edu.co
}

Received December, 2020

Accepted July, 2021

\section{Abstract}

Purpose: This study provides empirical evidence on the innovations that Nonprofit Organizations (NPOs) in Colombia have implemented within their own management to address social problems which are the object of their institutional mission.

Design/methodology: This research is based on information obtained from a survey applied to executives of Colombian NPOs. Multiple linear regression models were developed to check the partial effect of the set of independent variables (Organizational and Social Innovation) over the dependent variable (Organizational Performance). Main Components Analysis was applied to grouping the considered variables.

Findings: Empirical evidence indicates that Colombian NPOs are innovative organizations that advisedly follow management strategies for this purpose. Colombian NPOs have been innovating for their disposition to tackle the social problems implicated in their institutional mission. Evidence indicates that the main components derived from NPOs' organizational and social innovations are grouped into four: NPO innovation actions to adapt to the environment; internal innovation actions to improve NPO's performance; variables related with NPO innovation actions to improve their relations with external agents; innovation actions aimed at improving the management of social interventions associated with the mission of the NPOs and the management of institutional projects.

Research limitations/implications: The field work only used the survey technique to obtain the information and only assessed the perception of one of the directors of each of the NPOs participating in the study in terms of both the actions of organizational innovation such as social innovation and organizational performance. Therefore, the study undoubtedly presents bias in that perception.

The technique used for the selection of the sample of the participants was a non-probabilistic sampling, which implies bias in the information and therefore, limitation for the generalization of the results to other contexts. The geographical location of the administration of the NPOs was restricted to Bogota and surrounding municipalities.

Originality/value: An analysis of the relationship between social and organizational innovations with organizational performance in NPOs was carried out in the context of an emerging economy, where the subject has been very little studied and much less with principal component analysis. This in order to contribute to a better understanding of the subject. 
Keywords: Organizational innovation, Social innovation, Organizational performance, Innovation impacts, Non-profit organizations (NPOs)

Jel Codes: L25, L60, O14, O31, O32, O54

\section{To cite this article:}

Bernal-Torres, C.A., Montes-Guerra, M.I., Turriago-Hoyos, A., \& Fernando Castro-Silva, H. (2021). Organizational and social innovation in Non-Profit Organizations performance in the context of an emergent economy. Intangible Capital, 17(1), 73-90. https://doi.org/10.3926/ic.1731

\section{Introduction}

Undoubtedly, the role played by Nonprofit Organizations (NPOs) in developing countries is increasingly relevant basically for the innovation strategies required in different, diverse, uncertain, and complex social environments. These strategies should ensure the survival of NPO's sustainability (Dai, Lau \& Lee, 2019), and improve solutions to social problems which are part of their own institutional mission. Furthermore, NPOs require new strategies to identify, implement and provide effective services to their users (Laurett \& Ferreira, 2018; Park, Kim, Park \& Lim, 2018) and also to face the growing competition to secure funds, the complexity of problems in society derived from emerging issues such as COVID 19, donors who require transparency levels and more efficient management. In addition, it is important to highlight that, these organizations are important in developing countries as their social contributions generate large numbers of employment (CNIS, 2018) and volunteers (Southby, 2019).

Given the above mentioned, NPOs increasingly require more innovative strategies which enhance effectiveness and efficiency in their performance and in the end competitiveness (Lee, Ginn \& Naylor, 2009; Damanpour \& Aravind, 2011). This perspective has been shown by diverse studies indicating the direct relationship between innovation and performance efficiency of NPOs (Adro \& Fernandes, 2021; Anwar, Zaman Khan \& Ali Shah, 2020; do Adro \& Leitão, 2020; Zhang, Khan, Lee \& Salik,, 2019; Damanpour, 2017; Verschuere, Beddeleem \& Verlet, 2014).

Despite evidence of the importance of innovation on improving Organizational Performance and competitiveness (Doezema, Ludwig, Macnaghten, Shelley-Egan, \& Forsberg, 2019), many NPOs tend to resist innovation efforts (Netting \& Nelson, 2020; Hull \& Lio, 2006). any top managers and other members of these organizations do not understand the importance or the incentive as to why it is essential for their organizations to innovate (Winand, Scheerder, Vos, Zintz \& Hoeber, 2011). Hence, it is more difficult to develop the social competencies needed to impulse innovation in these organizations (Fuglsang \& Sundbo, 2005), especially when it comes to innovation within the management of these companies (Organizational Innovation), on the types and forms of service delivery, known as Social Innovation. (Jaskyte, 2018; Laurett \& Ferreira, 2018).

In the case of emerging economies, limited Organizational and Social Innovation deployment in many NPOs is due to the low flexibility in choosing their beneficiaries, low commitment to their mission, rigorous and ineffective control systems by both political and regulatory institutions, lack of coherence among internal members, and highly formalized, centralized, and standardized Organizational structure (do Adro \& Leitão, 2020; Winand et al., 2011). Low Organizational and Social Innovation levels in NPOs may also stem from low risk tolerance, partly due to their fragile financial structure and complex distribution of responsibilities and objectives (Park et al., 2018; Wit \& Mensink, 2019; Hull \& Lio, 2006).

In the specific case of Latin America, the condition of NPOs have been changing since the early 90s as a consequence of adapting to the social, economic, environmental, and political conditions of the region, including the pursuit of social inclusion, equity, solidarity, citizen's participation, human rights, and government transparency (Cáceres, 2014). Colombia exemplifies this situation as a country where from 1985 to 2016, more than eight million victims of armed conflict have been reported. Amongthese victims, there are 267,000 dead; 46,000 missing; 10,000 victims of antipersonnel mines; 17,000 cases of sexual abuse, largely women; one and a 
half million households displaced by violence and millions of people suffering from the death of a family member or loved one, who was sexually abused, illegally recruited by illegitimate armed groups in addition to cases of torture and kidnapping (Consejería Presidencial para los Derechos Humanos, 2018). According to data from the governmental statistical office, Departamento Administrativo de Estadística (DANE, 2018), 22\% of people are at the working age (particularly the youth and women) are unemployed; and $27 \%$ of the population $(13,073,000$ people) live in poverty. In the midst of this challenging social environment, Colombian NPOs are constantly facing great challenges in their mission to solve these social problems.

Based on the above, it is evident the need for more research oriented to assessing the relationship between innovation and performance effectiveness in NPOs, particularly in the context of emerging economies (Anwar et al., 2020; Lee et al., 2009; Damanpour \& Aravind, 2011). Moreover, existing results are inconclusive. About it, Baturina and Bežovan (2015) note that NPOs stakeholders evaluate these organizations from different points of view. Many aspects of social or Organizational Innovation consist of changes in the forms of work that in some cases are not directly perceived by the interest groups and, thus different investigations show a variety of findings, which in the case of NPOS in emerging economies the measurement culture is yet to be systematic (Anwar et al., 2020). Thus, this study was oriented to analyzing the Organizational and Social Innovations undertaken by current and active Colombian NPOs regarding their relationship to their own management and their approaches to addressing their mission towards social challenges. All of that seeks to provide empirical evidence for contributions to reflection and understanding of the relationship between social and Organizational Innovation with the performance of NPOs in emerging economies.

\section{Literature review}

\subsection{Social Innovation}

It is worth noting that Social Innovation is not specific to NPOs that seek to alleviate social problems (Wit \& Mensink, 2019; Murray, Caulier \& Mulgan, 2010). For Goldenberg, Kamoji, Orton and Williamson (2009), Corporate Social Responsibility (CSR) is a form of Social Innovation that responds to the demands of contemporary society in business organizations in exchange for the social benefits they obtain in their closed environment, but at the same time must not be used as a strategy to obtain higher economic benefits for the companies performing this activity.

According to Mulgan, Ali, Halkett and Sanders (2007), Social Innovation is the development and implementation of new ideas (products, services, and process) to satisfy social needs. For Mumford (2002), it is the creation and implementation of new ideas as to how people can organize interpersonal activities or social interactions to accomplish one or more common objectives with social benefits. Levésque (2012) on the other hand, conceives Social Innovation as a process to contribute to novel solutions to unsolved social problems.

Social Innovation according to Moulaert, MacCallum, Mehmood and Hamdouch (2013) emphasizes the satisfaction of the basic needs and changes in social relations in the social empowerment processes, referring to organizations and people that are affected by the depletion of the quality of their daily lives and services. In this same perspective, Biggs, Westley and Carpenter (2010) conceive it as the strategies, initiatives, changes in products, processes and organizations that satisfy the most urgent social needs, changes in the basic routines, redefinition of the authority schemes, or the belief in a social system. Howaldt and Schwartz (2010) consider it to be a new structure of social practices in action areas or social contexts and an initiative of certain actors seeking answers to needs and problems over the foundations of the already established practices.

For Godin (2012), Social Innovation is the way to build a society founded on the recognition, collaboration, inclusion, and equity between members that comprise society. While for Conejero (2016), this innovation includes actions oriented to satisfying human needs not addressed by government or the business sector. Furthermore, these are changes in the social relationships that occur with citizen participation in general, and particularly the most vulnerable groups of society and access to necessary resources to increase citizen empowerment in spite of the fact that NPOs' Social Innovation has to be at the center of their activity, due to challenges currently brought about by the diversity and complexity of current social problems in many parts of the world. 
Social Innovation contemplates the implementation of new Organizational forms, such as socially responsible companies or inclusive businesses in addition to providing spaces for the incorporation of voices of groups that have been traditionally excluded in the development process. Therefore, it creates various inclusion scenarios, which have contributed to several forms and implementation mechanisms (Vázquez-Maguirre \& Portales, 2018).

As seen above, there are several approximations to the Social Innovation concept, but for the purposes of this research, it would bead dressed broadly, as the set of products, new processes, and projects, developed by NPOs aimed at helping to solve social problems, with deep knowledge of their close environment using their own knowledge while realizing their activities collaboratively with other actors.

According to Ko et al. (2019), Moore and Westley (2011) and Westley and Antadze (2010), surprisingly, there has been little research aimed at understanding the nature and dynamics of this type of innovation carried out by such organizations and in particular the impacts of these innovations when it comes to deeply redressing the problems already mentioned. In general, research in this area has largely focused on the study of NPOs in the Netherlands which has been working towards innovative ideas to address the problem of climate change (Anheier, Krlev \& Mildenberger, 2018; Baturina \& Bežovan, 2015; Westley, Antadze, Riddell, Robinson \& Geobey, 2014). However, the results of these studies are still inconclusive, because empirical evidence shows that the relationship between Social Innovation and performance in NPOs depends largely on the diversity of Social Innovations that are implemented and, the context of the population served, among other aspects (Blanco-Ariza, Messino-Soza, Vázquez-García, \& Melamed-Varela, 2019; Taylor \& Arundel, 2019). Therefore, more studies on the subject are required particularly in countries like Colombia, given that the variety of social problems are part of the daily life of many people, especially those affected by both the armed conflict and poverty, which has brought about the proliferation of NPOs in the last decade.

\subsection{Organizational Innovation}

According to the European Commission (2004), Organizational Innovation refers to improvements in internal interactions within an organization such as collaboration between different units and the association and participation among different interest groups and the networks of their environment (other companies, assistance services, competence centers, research laboratories, etc.). Meanwhile, RICYT (Red Iberoamericana de Ciencia y Tecnología, 2004) conceives it as a significant change in routines and procedures in the management of organizations, Organizational structure, and changes their strategic orientation. Innovation in organizations involves learning processes that promote the development of teamwork knowledge and skills while facilitating adaptation to change and competitiveness (Claver-Cortés, Zaragoza Sáez \& González-Illescas, 2018). On the other hand, the authors Morente and Ferràs-Hernández (2017) consider that Organizational Innovation is related to innovation capacities, Organizational culture, personality, leadership, creativity, and entrepreneurship. In addition, OECD (2018) defines Organizational Innovation as the implementation of new Organizational methods such as business practices, roles, and external relationships. This conception is the one, which has been adopted in this research because its universality accepted by innovation scholars.

In this regard, according to Drucker (2005), the effective definition of an Organizational mission is the differentiating and innovating factor for an NPO as this is what drives the success of these entities. For Drucker (2005), a mission-based social organization will relate all key decisions to the mission and will require of all members continuous collaboration and innovation for it to be achieved.

According to Winand and Anagnostopoulos (2017), Miranda, Farias, de Araújo Schwartz and de Almeida (2016) and Verschuere et al. (2014), when NPOs adopt innovative behavior in the workplace and build new external relationships, they can respond competitively to changes in the environment and thereby improve their performance. Besides, NPOs that introduce new management techniques such as new managerial and human resource management styles (Oliveira, Sousa, Silva \& Santos, 2021; do Adro \& Leitão, 2020; Bastida, Marimon \& Carreras, 2018), new models of Organizational structures which strategically support knowledge management, learning and innovation (Dong, Yim \& Zhang, 2020; Dekoulou \& Trivellas, 2017; Dedahanov, Rhee, \& Yoon, 2017), new forms of collaborative work with stakeholders (Jevanesan, Antony, Rodgers \& Prashar, 2019; Laurett \& Ferreira, 2018), new strategies to identify donors of resources and, recruit volunteers (Schreiner, Trent, Prange \& Allen, 2018), new approaches to accessing technologies for their management, (McNutt, Guo, Goldkind \& 
An, 2018; Rathi \& Given, 2016) have better performance indicators that guarantee better sustainability in the short, medium and long run (Zhang. et al., 2019; Shin, Kang \& Bae, 2020).

Evidence suggests that the most successful and sustainable NPOs are those that operate in efficient and effective networks (Rodríguez, Carreras \& Sureda, 2012). In this sense, Waddell (2011) argues that NPOs achieve systemic change through participation in integrated networks comprised of several interest groups that surpass geographical, institutional, and sectorial frontiers. An increased use of web technologies has enhanced this network approach to managing and exchanging knowledge and have changed the way social organizations can identify new financing alternatives (Carreras, Iglesias \& Sureda, 2011).

Administrative styles, patterns of external and internal communication, managerial attitude towards change, and the technical capacity of the organization have effects on innovation of all kinds of organizations (Greenhalgh, Robert, Macfarlane, Bate \& Kyriakidou, 2004). For example, autocratic managerial styles, centralization, and formalization in decision making have a negative effect, while open and fluid communication have a positive effect (Tran, 2019).

According to Klassen, Dobni and Neufeldt (2020), Shin et al. (2020) and Dong et al. (2020) the set-up of an Organizational Innovation has a positive relationship with the performance of the NPOs matrix linked to the efficient use of their resources, the satisfaction of the beneficiaries, fundraising, reputation among peers, the capabilities to response to environmental changes, stakeholders demands and, effectiveness in achieving Organizational objectives.

Due to the aforementioned, the research studies of the Organizational Innovations of NPOs have been oriented towards their analysis within their context as a strategy to provide an argumentative response to the concern of managers and those of governmental agencies related to the activity of these organizations, in addition to donors, who guarantee quality management with efficiency (Oliveira et al., 2021; do Adro \& Leitão, 2020; Bastida et al., 2018, Urionabarrenechea, Lage \& Arrizabalaga, 2015).

These different studies have aimed at generating knowledge regarding taking advantage of Organizational Innovation to achieve effective management in NPOs using alternative strategies to those of organizations in the business world (Oliveira et al., 2021; do Adro \& Leitão,2020; Zhang., et al., 2019; Tran, 2019), which contributes to a better understanding of the issues of specific benefit to NPOs themselves, as well as their benefactors, donors, governmental agencies responsible for the surveillance and promotion of these organizations, and for academics interested in the subject.

\subsection{Organizational Performance}

NPOs must respond to many stakeholders and, therefore, expectations differ as to what they can or should accomplish. In this sense, NPOs face three different challenges related to results in their performance which include: meeting stakeholders' expectations, satisfying internal demands to maximize impact, and using results for learning and improvement (Saul, 2003). Although there is no consensus, most scholars agree that organization performance appraisal requires the measurement of multiple criteria including the evaluation of processes and the results of different Organizational functions (Giannopoulou, 2011; Shilbury \& Moore, 2006).

Therefore, for the purposes of this research, which analyzes the relationship of innovative activities with the performance of NPOs, it has been evidenced that the results of research indicate that the satisfaction of the beneficiaries is improved through innovations related to the diversity and quality of the programs and services offered. This makes the attraction to resources more effective through innovations aimed at optimizing the resources available to achieve institutional objectives. Furthermore, NPO reputation is improved by the degree of innovations implemented (Klassen et al., 2020; Verschuere et al., 2014; Giannopoulou; 2011; Bagnoli \& Megali, 2011).

Social organizations must give great value to effectiveness, efficiency, sustainability, and fairness of the process (Klassen et al., 2020; Zhang et al., 2019). This means that the generation, selection, and implementation of ideas that have become real must produce the highest social impact. In this regard, according to Hull and Lio (2006), despite the evidence of the importance of Organizational Innovation to improve Organizational Performance and competitiveness, there is research which indicates the existence of resistance to innovation in some NPOs. 
Based on the approaches described above, this study has sought to identify the Organizational and Social Innovations that these NPOs have employed in the last five years and specifically identifies the most influential set of innovations which have had the greatest impact on these organizations.

\section{Method}

The sources of information for this research were from the NPOs located in the greater Bogotá metropolitan area. Two hundred and seventy (270) organizations received invitation letters explaining the objectives and methodology of the study. From the organizations invited, 137 stated interest in participating, and 114 (83.21\%) completed the survey.

The sample of participating organizations was characterized by: include NPOs diversity -charitable NPOs (distribution of food, clothing or medicine; provision of housing, etc.), service (health, education, transportation), protection or defense (of human rights, women, children, immigrants, animals, the environment, etc.), community (religious, educational, gender, etc.), social associations (for the disabled, pensioners, marginalized groups, etc.), corporate social responsibility - business foundations (provision of housing, schools, shelters, etc.), among others; having at least five years of continuous activity at the time of the survey (the participating organizations reflected having an average of 18 years of operation); having a payroll of full-time workers with at least 10 people (the average number of workers of all NPOs in the sample was 67) and, Of these organizations, $83 \%$ were national and $17 \%$ international.

The survey format was designed by the authors specifically for this study, based on the literature review and according to the research objective which has sought to analyze the relationship between the fundamental aspects of innovation (Organizational and Social) and the performance of NPOs. In this sense, the questionnaire contained three sections: Organizational Innovation, consisting of 20 items mainly based on the those of the OCDE (2018), do Adro \& Leitão (2020), Oliveira et al. (2021), Dekoulou and Trivellas (2017), and Tran (2019), Social Innovation, based on 10 items mainly based on Baturina and Bežovan (2015), Mulgan et al. (2007), Biggs et al. (2010), and Conejero (2016) and Organizational Performance based on 8 items mainly based on Klassen et al. (2020) and Verschuere et al. (2014).

These three aspects were evaluated on a Likert scale, from 1 to 5 where: $1=$ Strongly disagree, $2=$ Partially disagree, $3=$ Indifferent, $4=$ Partially agree and $5=$ Strongly agree. For validation, three expert psychologists in NPOs reviewed and made proposals for adjustments to the questionnaire. Also,15 executives of these organizations pilot tested the questionnaire. With the recommendations of the psychologists, shortcomings were identified in the pilot test applied to the 15 executives, enabling the defining of the questionnaire used to obtain the data about the NPOs.

Researchers and a group of four research assistants applied the questionnaire in person by visiting the executives of the participating organizations at their work site. Data was recollected during May and October 2019 through questionnaires.

For data processing, Fisher $\mathrm{F}$ test was used in each one of the multiple linear regression models to check the partial effect of the set of independent variables (Organizational and Social Innovation) over the dependent variable (Organizational Performance).To verify the compliance of the assumptions in each one of these regression models, the following statistical tests were applied: White's test or the assumption of homoscedasticity that allows to contrast nonlinearities by calculating the squares and crossed products of the predictors, DurbinWatson test was used to check the non-correlation of errors (et) computing the coefficient, The Shapiro-Wilks test to verify normality of errors.

\section{Results}

The results of the study are shown at three levels: Descriptive to illustrate NPO Organizational and Social Innovation actions performance effectiveness, Multiple regression to establish the impact of the different actions of Organizational and Social Innovation on the performance of the NPOs through an optimal linear regression model that explains the behavior of each one of the variables or constituent variables of performance, Main 
Component Analysis (MCA) to identify the group of Organizational and Social Innovation actions that contribute the most to changes in the performance of these organizations.

\subsection{Descriptive analysis}

In general terms, executives stated that during the past three years of activity, their organizations have participated in diverse innovation actions (Organizational Innovation with an average score of 4.15/5.0 and Social Innovation with an average score 4.17/5.0) and that the effectiveness in the Organizational Performance has been positive (score 4.17/5.0). These results indicate that these organizations give relevance to innovation as one of the strategies to achieve their Organizational objectives. This positive attitude toward innovation by the organizations participating in this study is reason for recognition because it shows that these organizations are concerned and work towards responding to the challenges and demands of diversity and complexity of social problems faced by these developing countries.

These positive results show that NPOs in their willingness for both, Organizational and Social Innovation, could be largely due to the competition that has been taking place in Colombia in recent years among NPOs to attract resources from donors of developed countries. These donors are interested in providing resources oriented specifically to finance projects for populations affected by the armed conflict and natural disasters, but that demand from the NPOs working with these populations should demonstrate efficiency and transparency in the use of these resources. The results may also be supported by the fact that various actors in Colombian society have begun to require greater professionalism on the part of NPOs in the management of the resources allocated to them in order to work with marginalized communities.

Table 1 shows the averages of each one of the categories included in Organizational Innovation, Social Innovation, and Organizational Performance. Regarding the set of items in Organizational Innovation, the highest average is found in the issue,"Management style changes have improved Organizational Performance." which scored 4.27 and the lowest value 3.32 is for "Job responsibilities have changed". For Social Innovation, a maximum was obtained in "Improvement in the ability to identify, assimilate, transform, and exploit external knowledge to solve community problems related to the mission of the NPO" with 4.20, and the lowest value was 3.68 for "Some NPO members have identified social needs related to the institutional mission.". Finally, for Organizational Performance, the highest value of 4.28 is for "Available results have been obtained in achieving the institutional objectives". The lowest was "Increase the diversity of sources of financing for development" with 3.27 .

\begin{tabular}{|c|l|r|}
\hline Item & \multicolumn{1}{|c}{ Organizational Innovation } & Average \\
\hline 1 & Positive flexibility toward environmental changes. & 4.24 \\
\hline 2 & Management easily absorbs environment changes. & 3.96 \\
\hline 3 & Management style changes have improved Organizational Performance. & 4.27 \\
\hline 4 & Managers have introduced changes that allow workers to be more effective. & 4.11 \\
\hline 5 & Managers have promoted change in their employees to achieve better performance results. & 4.05 \\
\hline 6 & Improvements in work methods resulting in new and better services & 4.13 \\
\hline & $\begin{array}{l}\text { The use of new technologies to improve the performance of personnel and improve their service has } \\
\text { been promoted. }\end{array}$ & 4.03 \\
\hline 8 & Human resources develop their own work approaches. & 3.92 \\
\hline 9 & Majority of employee roles has changed depending on the situation of the NPOs. & 4.00 \\
\hline 10 & Management has based its decisions on general policies that adapt to present demands. & 4.02 \\
\hline 11 & Human resource management has changed. & 3.69 \\
\hline 12 & The way they relate to users has changed. & 4.06 \\
\hline 13 & Relationships with sponsors have changed. & 4.06 \\
\hline 14 & Relationships with the community have changed. & 4.01 \\
\hline 15 & Management has promoted personnel initiative to achieve new sources of financing. & 3.73 \\
\hline & $\begin{array}{l}\text { Cooperative activities between NPOs and other public or private entities has been promoted to improve } \\
\text { their service. }\end{array}$ & 4.03 \\
\hline 17 & $\begin{array}{l}\text { Organizational structure has modified by responding to changes in the internal and external } \\
\text { environment of the organization. }\end{array}$ & 3.63 \\
\hline 18 & Job responsibilities have changed. & 3.32 \\
\hline 19 & Frequent training activities to improve worker performance. & 3.80 \\
\hline
\end{tabular}




\begin{tabular}{|c|c|c|}
\hline Item & Organizational Innovation & Average \\
\hline \multirow[t]{3}{*}{20} & $\begin{array}{l}\text { Exchange of ideas. knowledge, and relevant information between members of the organization has } \\
\text { been promoted to improve the activities of the organization. }\end{array}$ & 4.14 \\
\hline & Average Organization Innovation & 3.96 \\
\hline & Social Innovation & \\
\hline 21 & $\begin{array}{l}\text { Improvement in the ability to identify, assimilate, transform, and exploit external knowledge to solve } \\
\text { community problems related to the mission of the NPO }\end{array}$ & 4.20 \\
\hline 22 & New ideas have deployed novel ways and processes for offering services. & 4.12 \\
\hline 23 & $\begin{array}{l}\text { Linkage with external agents to exchange information and knowledge contribute to achieving the } \\
\text { mission }\end{array}$ & 4.18 \\
\hline 24 & Some NPO members have identified social needs related to the institutional mission. & 3.68 \\
\hline 25 & $\begin{array}{l}\text { A diversity of sources exists (users, expert and academic institution reports, seminars, etc.) for ideas } \\
\text { related to the development of the organization's social projects. }\end{array}$ & 3.97 \\
\hline 26 & $\begin{array}{l}\text { There is diversity in the cooperation between partners for the development of social projects of the } \\
\text { institutional mission. }\end{array}$ & 3.76 \\
\hline 27 & Initiatives involving users working together to solve group problems have been promoted. & 3.96 \\
\hline 28 & There are different social intervention modes. & 4.03 \\
\hline 29 & $\begin{array}{l}\text { The diversity of results in the sectorial impact of the social projects of the Organizational mission has } \\
\text { been generated. }\end{array}$ & 4.00 \\
\hline \multirow[t]{3}{*}{30} & Projects have created new Organizational infrastructures. & 3.89 \\
\hline & Average Social Innovation & 3.98 \\
\hline & OrganizationalPerformance & \\
\hline 31 & NPOs' Organizational culture has been improved & 3.96 \\
\hline 32 & Relations with users have been improved & 4.21 \\
\hline 33 & NPOs' effectiveness has improved in order to develop their mission & 4.07 \\
\hline 34 & Increasing the diversity of funding sources for development & 3.27 \\
\hline 35 & Improving perception of users' requirements & 4.08 \\
\hline 36 & Consolidated teamwork between NPOs and community agents & 4.07 \\
\hline 37 & Available resource efficiency for missional purposes is improved. & 4.14 \\
\hline \multirow[t]{2}{*}{38} & Available results have been obtained in achieving the institutional objectives & 4.28 \\
\hline & Average Organizational Performance & 4.01 \\
\hline
\end{tabular}

Table 1. Average percentage in the items of Social Innovation, Organizational Innovation, and Organizational Performance

\subsection{Multiple Regression Analysis}

To establish the impact of different items of Organizational and Social Innovation on the Performance of NPO's, an optimal linear regression model was applied to identify the trend and interrelationships among each one of the seven performance items (dependent variable) based on the 30 items related to innovation actions (independent variables) which were implemented in NPOs.

Table 2 shows that, with a confidence level of 95\% judging by the $p$-value obtained when applying the Fisher $\mathrm{F}$ test in each one of the multiple linear regression models, there is sufficient evidence to confirm that aspects of the independent variables (Organizational Innovation and Social Innovation) allow for an explanation of the variability of the dependent variable (NPOs' performance). For example, as shown in Table 2 for the dependent variable -NPO's performance-, which is item 5 , is related to an increase in real knowledge of the needs of NPO users, the linear regression model composed of 30 items related to Organizational and Social Innovation explains $80.9 \%$ (column R2) of the performance variability.

\begin{tabular}{|c|c|c|c|c|}
\hline Aspects of the Organizational Performance. & $\mathbf{R}^{2}$ & df & $\mathbf{F}$ & $P$-Value \\
\hline 1. Improvements in Organizational culture. & 0.729 & 30 & 3.024 & 0.000 \\
\hline 2. Improvement in relationships with users. & 0.811 & 30 & 4.220 & 0.000 \\
\hline $\begin{array}{l}\text { 3. Improvement in the effectiveness of the NPOs for the } \\
\text { development of their mission. }\end{array}$ & 0.663 & 30 & 2.094 & 0.005 \\
\hline 4. Diversity of project financing sources. & 0.711 & 30 & 2.725 & 0.000 \\
\hline 5. Better knowledge of user needs. & 0.809 & 30 & 5.051 & 0.000 \\
\hline 6. Consolidated teamwork between NPOs and community agents. & 0.771 & 30 & 3.909 & 0.000 \\
\hline 7. More efficient, mission-based resource usage. & 0.752 & 30 & 3.470 & 0.000 \\
\hline
\end{tabular}

Table 2. Percentage in which the activities of Organizational and Social Innovation explain the variability of some of the indicators of NPOs' performance 
Data from Table 3 identifies the explaining aspects with more relative influence over the dependent variables, taking as criteria standardized regression coefficients.

\begin{tabular}{|c|c|c|}
\hline $\begin{array}{c}\text { Dependent } \\
\text { variable (NPO } \\
\text { performance) }\end{array}$ & \begin{tabular}{|c|}
$\begin{array}{c}\text { Standardized } \\
\text { 'd' regression } \\
\text { coefficient }\end{array}$ \\
\end{tabular} & Innovation's aspect with greater relative influence \\
\hline \multirow{6}{*}{$\begin{array}{c}(1) \\
\text { Improvements in } \\
\text { Organizational } \\
\text { culture }\end{array}$} & 0.119 & 30. Projects have created new Organizational infrastructures. \\
\hline & 0.123 & 28. There are different social intervention modes. \\
\hline & 0.105 & 8. Human resources develop their own work approaches. \\
\hline & 0.076 & 18. Job responsibilities have changed. \\
\hline & 0.074 & 13. Sponsor relationships have changed. \\
\hline & 0.074 & $\begin{array}{l}\text { 16. Cooperative activities between NPOs and other public or private entities has been } \\
\text { promoted to improve their service. }\end{array}$ \\
\hline \multirow{5}{*}{$\begin{array}{l}\text { (2) } \\
\text { Improvement in } \\
\text { relationships with } \\
\text { users }\end{array}$} & 0.378 & 30. Projects have created new Organizational infrastructures. \\
\hline & 0.215 & 28. There are different social intervention modes. \\
\hline & 0.123 & 3. Management style changes have improved Organizational Performance. \\
\hline & 0.098 & 22. New ideas have deployed novel ways and processes for offering services. \\
\hline & 0.080 & 11. Human resource management has changed. \\
\hline \multirow{5}{*}{$\begin{array}{l}\text { (3) } \\
\text { Improvement in the } \\
\text { effectiveness of the } \\
\text { NPOs for the } \\
\text { development of } \\
\text { their mission }\end{array}$} & 0.353 & 30. Projects have created new Organizational infras \\
\hline & 0.197 & 28. There are different social intervention modes. \\
\hline & 0.144 & $\begin{array}{l}\text { 16. Cooperative activities between NPOs and other public or private entities have } \\
\text { been promoted to improve their service. }\end{array}$ \\
\hline & 0.138 & 13. Sponsor's relationships have changed. \\
\hline & 0.093 & 8. Human resources develop their own work approaches. \\
\hline \multirow{5}{*}{$\begin{array}{l}\text { (4) } \\
\text { Diversity of project } \\
\text { financing sources }\end{array}$} & 0.890 & 30. Projects have created new Organizational infra \\
\hline & 0.132 & 13. Relationships with sponsors have changed. \\
\hline & 0.169 & 28. There are different social intervention modes. \\
\hline & 0.133 & $\begin{array}{l}\text { 16. Cooperative activities between NPOs and other public or private entities have } \\
\text { been promoted to improve their service. }\end{array}$ \\
\hline & 0.143 & $\begin{array}{l}\text { 23. Linkage with external agents to exchange information and knowledge contribute } \\
\text { to achieving the mission. }\end{array}$ \\
\hline \multirow{5}{*}{$\begin{array}{c}(5) \\
\text { Better knowledge } \\
\text { of user needs }\end{array}$} & 0.126 & 2. Management easily absorbs environment changes. \\
\hline & 0.145 & 6. Improvements in work methods resulting in new and better services \\
\hline & -0.280 & 9. Majority of employee roles has changed depending on the situation of the NPOs. \\
\hline & 0.237 & 14. Relationships with the community have changed. \\
\hline & 0.290 & $\begin{array}{l}\text { 21. Improvement in the ability to identify, assimilate, transform, and exploit external } \\
\text { knowledge to solve community problems related to the mission of the NPO. }\end{array}$ \\
\hline $\begin{array}{c}\text { Dependent } \\
\text { variable (NPO } \\
\text { performance) }\end{array}$ & $\begin{array}{l}\text { Standardize } \\
d \text { 'd' } \\
\text { regression } \\
\text { coefficient }\end{array}$ & Innovation's aspect with greater relative influence \\
\hline \multirow{5}{*}{$\begin{array}{c}(6) \\
\text { Consolidated } \\
\text { teamwork between } \\
\text { the NPO and } \\
\text { community agents }\end{array}$} & 0.127 & 13. Relationships with sponsors have changed. \\
\hline & 0.123 & $\begin{array}{l}\text { 16. Cooperative activities between NPOs and other public or private entities have } \\
\text { been promoted to improve their service. }\end{array}$ \\
\hline & 0.178 & 19. Frequent training activities to improve worker performance. \\
\hline & 0.161 & 22. New ideas have deployed novel ways and processes for offering services. \\
\hline & 0.102 & $\begin{array}{l}\text { 23. Linkage with external agents to exchange information and knowledge contribute } \\
\text { to achieving the mission. }\end{array}$ \\
\hline \multirow{5}{*}{$\begin{array}{l}\quad(7) \\
\text { More efficient, } \\
\text { mission-based } \\
\text { resource usage. }\end{array}$} & 0.181 & 1. Positive flexibility toward environmental changes. \\
\hline & 0.131 & 3. Management style changes have improved Organizational Performance. \\
\hline & 0.166 & 11. Human resource management has changed. \\
\hline & 0.242 & $\begin{array}{l}\text { 24. Some NPO members have identified social needs related to the institutional } \\
\text { mission. }\end{array}$ \\
\hline & 0.211 & 4. Managers have introduced changes that allow workers to be more effective. \\
\hline
\end{tabular}

Table 3. Organizational and Social Innovation activities that explain the main indicators of the Organizational Performance of NPOs 
The activities identified in this study such as actions of Organizational Innovation and Social Innovation in Colombian NPOs explains each one of the items associated with Organizational Performance such as: Improvement in Organizational Culture, Improvement in Relations with Users, The Increase in the Effectiveness of NPOs in Carrying out their Mission, The Diversity of Sources of Financing for Institutional Projects, Better Understanding of User Needs, Consolidation of Teamwork between the NPO and Community Agents, Greater Efficiency in the Use of the NPO's Resources for the Development of its Mission and, The Best Results in Achieving the NPOs Objectives.

\subsection{Main Components Analysis}

MCA was applied to find a reduction in data through correlation analysis with the above data set that make up Organizational and Social Innovation. The Barlett Sphericity test result of 0.69 and the p-value obtained (Table 4) indicate that the null hypothesis implicit in the regression can be rejected; and therefore, the relationships and correlations between the innovation variables are significant and that it is appropriate to perform an MCA for the sample data obtained in this study.

\begin{tabular}{|l|l|r|}
\hline Kaiser-Meyer-Olkin measure of sampling adequacy & $\mathbf{0 . 8 6 9}$ \\
\hline \multirow{3}{*}{ Barlett's sphericity test } & Approx. Chi-squared & $2,271.516$ \\
\cline { 2 - 3 } & Degrees of freedom & 703 \\
\cline { 2 - 3 } & P value & 0.000 \\
\hline
\end{tabular}

Table 4. A measure of the appropriateness of applying the MCA method

Table 5 shows the progression of the total variance as the number of factors increases. Grouping the set of variables or aspects of innovation in four components explains approximately $82 \%$ of the total variability of the sample data. The decision to assign each one of the items to one of the 4 components was made considering the squared cosines of each one of the variables, obtaining the conformation of the components shown in Table 6.

\begin{tabular}{|l|r|r|r|r|r|r|}
\hline \multirow{2}{*}{$\begin{array}{l}\text { Number of aspects or } \\
\text { components }\end{array}$} & \multicolumn{3}{|c|}{ Initial Eigen Values } & \multicolumn{3}{c|}{ Sums of Load Removal Squared } \\
\cline { 2 - 7 } & \multicolumn{1}{c|}{ Total } & \% Variance & \% Accumulated & \multicolumn{1}{c|}{ Total } & \% Variance & \% Accumulated \\
\hline 1 & 10.853 & 46.177 & 36.177 & 10.853 & 46.177 & 46.177 \\
\hline 2 & 2.054 & 15.848 & 53.025 & 2.054 & 15.848 & 62.025 \\
\hline 3 & 1.704 & 12.678 & 68.703 & 1.704 & 12.678 & 74.703 \\
\hline 4 & 1.587 & 7.292 & 53.995 & 1.587 & 7.292 & 81.995 \\
\hline 5 & 1.349 & 2.498 & 58.493 & 1.349 & 2.498 & 84.493 \\
\hline 6 & 1.087 & 1.624 & 82.117 & 1.087 & 1.624 & 86.117 \\
\hline 7 & .990 & 1.300 & 85.417 & & & \\
\hline$\ldots$ & $\ldots$ & $\ldots$ & $\ldots$ & & & \\
\hline 30 & .110 & .367 & 100.000 & & & \\
\hline
\end{tabular}

Table 5. Total variance explained by the factors

It is important to clarify that, the values expressed in the Initial Eigen Values show the results starting from the initial 30 items, while the Sums of Load Removal Squared correspond to the results when working with six main components (Table 5). However, for the purposes of this study, we worked with the results of the first 4 components, which best explain the variance of the data.

Thus, once the squared cosines of the variables included in the analysis of the main components MCA were analyzed, they were grouped in four components, as shown in Table 5. Variables included in each factor are correlated, and most of them refer to a common topic that allows assigning a name to each one of the components. Thus, Component 1 refers to NPO innovation actions to adapt to the environment. Component 2 groups the variables related with NPO internal innovation actions to improve their performance, mainly aimed at human direction. Component 3 includes the variables related with NPO innovation actions to improve their relations with external agents such as users and public and private entities. Finally, Component 4 groups the variables related with innovation actions aimed at improving the management of social interventions associated with the mission of the NPOs and the management of institutional projects. 
The information in Table 6 shows that, in Component 1 (Adaptation to the environment), which is made up of 7 items had the greatest relevance and this is evidenced in the importance of Flexibility and a positive attitude towards change (4.24); Exchange of ideas and knowledge among its members (4.14); Based on management decisions for the demand of their services (4.02), and the items of less relevance are Changes in jobs (3.32) and in Administrative structure (3.63). In Component 2 (Internal changes in the administration) consisting of 8 items and, the most relevant is the Introduction of changes to improve work methods (4.14), and Better performance (4.12), and the least relevant is the Lack of changes in the way of managing people (3.69). In Component 3 (Integration with external agents) made up of 8 items, the most relevant are Changes generated in the organization to improve its performance (4.27), and Initiatives to carry out joint work with the users for the effectiveness in solving problems (4.20); and the least relevant is the Implementation of ideas related to process improvement. In Component 4 (Management of social intervention and projects) made up of 7 items, the most relevant is Fostering the link with external agents for the exchange of information, and Knowledge that contributes to the achievement of the institutional mission (4.18); the least relevant is To promote initiatives of the personnel to obtain new sources of financing (3.73).

\begin{tabular}{|c|c|c|}
\hline $\begin{array}{l}\text { Description } \\
\text { of the factor }\end{array}$ & Performance indicators grouped by factors & Average \\
\hline \multirow{7}{*}{$\begin{array}{c}1 . \\
\text { NPO } \\
\text { adaptation to } \\
\text { the } \\
\text { environment }\end{array}$} & 1.Positive flexibility toward environmental changes. & 4.24 \\
\hline & 2.Management has adapted easily to the changes in the environment. & 3.96 \\
\hline & 10. Management has based its decisions on general policies that adapt to present demands. & 4.02 \\
\hline & $\begin{array}{l}\text { 17. Organizational structure has modified by responding to changes in the internal and external } \\
\text { environment of the organization. }\end{array}$ & 3.63 \\
\hline & 18. Job positions have changed. & 3.32 \\
\hline & $\begin{array}{l}\text { 20. Exchange of ideas, knowledge, and relevant information between members of the } \\
\text { organization has been promoted to improve the activities of the organization. }\end{array}$ & 4.14 \\
\hline & $\begin{array}{l}\text { 24. Some members of the NPO have identified social needs or demands related to the } \\
\text { institutional mission. }\end{array}$ & 3.68 \\
\hline \multirow{8}{*}{$\begin{array}{c}2 . \\
\text { Internal } \\
\text { changes in the } \\
\text { management } \\
\text { of the NPO }\end{array}$} & 4. Managers have introduced changes that allow workers to be more effective. & 4.12 \\
\hline & 5. Managers have promoted change in their employees to achieve better performance results. & 4.05 \\
\hline & 6. Improvements in work methods resulting in new and better services. & 4.14 \\
\hline & $\begin{array}{l}\text { 7. The use of new technologies to improve the performance of personnel and improve their } \\
\text { service has been promoted. }\end{array}$ & 4.03 \\
\hline & 8. Human resources develop their own work approaches. & 3.92 \\
\hline & 9. Majority of employee roles has changed depending on the situation of the NPOs. & $4 ; 00$ \\
\hline & 11. Human resource management has changed. & 3.69 \\
\hline & 19. Frequent training activities to improve worker performance. & 3.80 \\
\hline \multirow{8}{*}{$\begin{array}{c}3 . \\
\text { Integration } \\
\text { with external } \\
\text { agents }\end{array}$} & 2.Management style changes have improved Organizational Performance. & 4.27 \\
\hline & 13. Relationships with sponsors have changed. & 4.06 \\
\hline & 14. Relationships with the community have changed. & 4.01 \\
\hline & $\begin{array}{l}\text { 16. Cooperative activities between NPOs and other public or private entities has been } \\
\text { promoted to improve their service. }\end{array}$ & 4.03 \\
\hline & $\begin{array}{l}\text { 21. Improvement in the ability to identify, assimilate, transform, and exploit external knowledge } \\
\text { to solve community problems related to the mission of the NPO. }\end{array}$ & 4.12 \\
\hline & 22. New ideas have deployed novel ways and processes for offering services. & 3.76 \\
\hline & $\begin{array}{l}\text { 26. There is diversity in the cooperation between partners for the development of social } \\
\text { projects of the institutional mission. }\end{array}$ & 3.96 \\
\hline & 27. Initiatives involving users working together to solve group problems have been promoted. & 4.20 \\
\hline \multirow{7}{*}{$\begin{array}{c}4 . \\
\text { Management } \\
\text { of social } \\
\text { intervention } \\
\text { and projects }\end{array}$} & 12. The way they relate to users has changed. & 4.07 \\
\hline & 15. Management has promoted personnel initiative to achieve new sources of financing. & 3.73 \\
\hline & $\begin{array}{l}\text { 23. Linkage with external agents to exchange information and knowledge contribute to } \\
\text { achieving the mission. }\end{array}$ & 4.18 \\
\hline & $\begin{array}{l}\text { 25. A diversity of sources exists (users, expert and academic institution reports, seminars, etc.) } \\
\text { for ideas related to the development of the organization's social projects. }\end{array}$ & 3.97 \\
\hline & 28. There are different social intervention modes. & 4.03 \\
\hline & $\begin{array}{l}\text { 29. The diversity of results in the sectorial impact of the social projects of the Organizational } \\
\text { mission has been generated. }\end{array}$ & 4.00 \\
\hline & $\begin{array}{l}\text { 30. Projects have created new infrastructure that gives life to the action of the NPO beyond the } \\
\text { project. }\end{array}$ & 3.89 \\
\hline
\end{tabular}

Table 6. Grouping of the variables in the four main components based on square cosines 


\section{Discussion and conclusions}

This study has been oriented to analyzing the relationship between Organizational Innovation (changes in aspects related to the administration of organizations) and Social Innovation (new ways of addressing social problems) with NPOs' Organizational Performance in the context of Colombian society. A literature review was conducted for each of these innovations indicating that in the context of emerging economies there is a lack of research on the subject without conclusive results. This has also considered that in these economies research on the subject is very scarce even though NPOs have a great role in solving the diversity of social problems permanently faced by these societies. Therefore, the results of this study provide the following contributions to the understanding of this field of research:

First, empirical evidence indicates that Colombian NPOs are innovative organizations that advisedly follow management strategies for this purpose. Changes in the Organizational structure, work methods and means of managing staff, relationships with their benefactors, implementation of new strategies for joint work with public and private entities, are good examples of these deliberate strategies. These results coincide with the findings of Park et al. (2018), Wit and Mensink (2019) who have pointed out that because NPOs face an increasingly complex, uncertain, competitive and globalized environment, and an increasing shortage of resources, the result is a strong innovation improvement derived from interactions with donors of the resources and their benefactors. However, contrasts with the approaches of Fuglsang and Sundbo (2005), Hull and Lio (2006), and Winand et al. (2011) provide evidence that NPOs, including those from developing countries, tend to give little relevance to innovation as a strategy for their own survival, largely due to measures to their resistance to change, and low tolerance towards risk. On the other hand, Colombian NPOs in this study have been innovating for their disposition to tackle the social problems implicated in their institutional mission. An example of this are the new strategies these organizations use to identify the needs of the benefactors. For instance, the finding of new resources allocated to NPO's social projects, the use of new alternatives to solve social problems, the diversification of partners for the development of projects and management strategies that imply working in teams with benefactors.

These results contribute to a better understanding of NPOs' Social Innovation. As Wit and Mensink (2019), Moore and Westley (2011) and Westley and Antadze (2010) state, little research has been done in the nature and dynamics of this type of innovation carried out by NPOs, particularly when it comes to the successes of these innovations towards the contribution to the solution of problems and basically, because the results of the existing studies about subject are yet to be concluded, because it depends on variables such as the context of the intervention, the population served and the type of service offered by the organization (Blanco-Ariza, et al., 2019, Taylor \& Arundel, 2019). Researching the Social Innovation carried out by NPOs in socioeconomical contexts such as that of Colombia is indeed important because there is a large population that has had to face the impacts of a fifty-year-old armed conflict. In addition, Colombians have had to face difficulties in satisfying basic needs due to the depletion or lack of quality in daily life. For this reason, according to Moulaert, et al. (2013) and Biggs et al. (2010), NPOs demand new strategies, initiatives, processes for working together with benefactors, donors, and governmental agencies, to contribute, using innovative approaches to solving pressing problems that overwhelm the population.

The second one evidences that Organizational Innovation and Social Innovation carried out by active Colombian NPOs significantly explain each one of the aspects associated with their Organizational Performance such as: 1) improvement in the Organizational culture; 2) improvement in relations with beneficiaries; 3) increase in the effectiveness of NPOs for the development of their mission; 4) diversity of funding sources for institutional projects; 5) best knowledge of beneficiaries' needs; 6) consolidation of teamwork between the NPOs and community agents; 7) greater efficiency in the use of NPO's resources for the development of their mission. These results are consistent with Lee et al. (2009), Damanpour and Aravind (2011), Packard (2010) and Conejero (2016) who agree that there is a direct relationship between innovative actions and NPOs' performance.

The third one has to do with evidence which indicates that the main components derived from NPOs' Organizational and Social Innovations are grouped into four components: the first one, refers to NPOs' innovation actions of adaptation to their own environment; the second one, actions of internal NPOs' 
innovation that improve their management that includes innovation actions improving their relationships with external agents such as beneficiaries and public and private entities. The final result is the component that groups the innovation actions aimed at improving the management of social interventions associated with the mission of the NPOs and the management of their institutional projects.

The identification of these main components of Organizational and Social Innovation that influence NPOs' performance is very important, because they serve as a reference guide for NPOs. This analysis also contributes to answering the concern of Hull and Lio (2006) who affirm that, despite the evidence on the importance of innovation to improve performance and Organizational competitiveness, there is resistance to innovation by many non-profit organizations for profit gains. This resistance according to Winand et al. (2011) is due to the fact that managers have not understood the importance of innovation to their organizations. According to Fuglsang and Sundbo (2005) this resistance, to innovate, obeys the fact that in these organizations it is difficult to develop the necessary social skills to boost the innovation. Winand et al. (2011), referring to the case of NPOs in developing countries, attributes this gap to the lack of flexibility in the orientation of their users, exposure to a high commitment to their mission, the rigorous systems of control by political and regulatory institutions, as well as by their internal members, since these organizations are usually highly formal, centralized in decision-making, and standardized in their procedures.

In summary, the results of the study contribute to a reflection by directors of NPOs, government agencies that support these types of organizations, and scholars given their importance in developing societies towards alleviating social problems.

\section{Implications}

The results of this study contribute to an academic reflection on the subject in the context of NPOs in emerging countries, where not only there is a lack of research in the area, but also where the results are inconclusive. From the point of view of the empirical evidence, the study is a great contribution to the managers of the NPOs themselves, for those responsible for promotion and surveillance in state agencies and similar organizations, for the donors of resources destined to contributing towards alleviating social problems with the intermediation of NPOs, the benefactors themselves and in general for anyone interested in the issue of NPO activity.

Undoubtedly, NPOs play an important role in societies for their contribution to solving social problems among the less favored groups in the population, but the need for these organizations to beincreasingly effective in achieving their objectives is also unquestionable as the society requires NPOs with an optimal use of resources for their benefactors.

The results of this study are important in terms of the development and improvement of the quality of life in emerging countries such as Colombia, where there is a large mobilization of resources to carry out social development projects, which are mostly executed by NPOs. Based on the results of the study carried out by Anwar, et al. (2020), where a positive relationship was found between innovation and NPO performance, it can be stated that Organizational and Social Innovation actions are developed impacting performance and that aid is more effective and efficient as these organizations are geared towards social development.

Performance are measures that allow organizations to evaluate their impact. In the case of NPOs, as their approach is to contribute to the development of less favored populations, this study generates important contributions, so that aid executed through projects has a greater impact and reaches a larger number of the population. This affirms the commitment of these organizations to providing social services and promoting community development among others, confirming that innovation can positively complement the management of NPOs (Blanco-Ariza et al., 2019).

\section{Limitations and future research}

This study presents, among others, the following limitations:

The field work only used the survey technique to obtain the information and only assessed the perception of one of the directors of each of the NPOs participating in the study in terms of both the actions of 
Organizational Innovation such as Social Innovation and Organizational Performance. Therefore, the study undoubtedly presents bias in that perception.

The technique used for the selection of the sample of the participants was non-probabilistic sampling, due to its user-friendliness and availability of access to information from NPOs, which implies bias in the information and therefore, limitation for the generalization of the results to other contexts. The geographical location of the administration of the NPOs was restricted to Bogota and surrounding municipalities, which is the area with the largest number of headquarters of these types of organizations and NPOs based in areas outside Bogota were not considered. The research was based in the city of Bogotá, venue of the researchers and the interviews with executives were conducted in their offices to reduce travel costs, which could narrow the scope of research.

As a result of the aforementioned limitations and the findings of the study, it is suggested that in future research the issue of Organizational and Social Innovations in NPOs should be analyzed in more detail, including a larger sample of organizations in addition to a larger population size to obtain more information about the context and focus of the services offered to the NPO.

\section{Acknowledgments}

We express our gratitude to the research assistant Simón Vásquez-Gutiérrez for his great support in the fieldwork of this study.

\section{Declaration of Conflicting Interests}

The authors declared no potential conflicts of interest with respect to the research, authorship, and/or publication of this article.

\section{Funding}

The authors received no financial support for the research, authorship, and/or publication of this article.

\section{References}

Adro, F.D., \& Fernandes, C. (2021). Social entrepreneurship and Social Innovation: Looking inside the box and moving out of it. Innovation: The European Journal of Social Science Research, 1-27. https://doi.org/10.1080/13511610.2020.1870441

Anheier, H., Krlev, G., \& Mildenberger, G. (2018). Social Innovation [Open Access]: Comparative Perspectives. Oxford, UK: Routledge. https://doi.org/10.4324/9781315158020

Anwar, M., Zaman Khan, S., \& Ali Shah, S.Z. (2020). A study of the relationship between innovation and performance among NPOs in Pakistan. Journal of Social Service Research, 46(1), 26-40. https://doi.org/10.1080/01488376.2018.1516265

Bagnoli, L., \& Megali, C. (2011). Measuring Performance in Social Enterprises. Nonprofit and Voluntary Sector Quarterly, 40 (1), 149-165. https:// doi.org/10.1177/0899764009351111

Bastida, R., Marimon, F., \& Carreras, L. (2018). Human resource management practices and employee job satisfaction in nonprofit organizations. Annals of Public and Cooperative Economics, 89(2), 323-338. https://doi.org/10.1111/apce.12181

Baturina, D., \& Bežovan, G. (2015). Social Innovation impact-review no. 9. Seventh Framework Programme (grant agreement 613034), European Union, Brussels: Third Sector Impact.

Biggs, R., Westley, F.R., \& Carpenter, S.R. (2010). Navigating the back loop: Fostering Social Innovation and transformation in ecosystem management. Ecology and Society, 15(2), 1-15. Retrieved from: http://www.ecologyandsociety.org/vol15/iss2/art9/https://www.jstor.org/stable/26268153 https://doi.org/10.5751/ES-03411-150209

Blanco-Ariza, A.B., Messino-Soza, A., Vázquez-García, Á.W., \& Melamed-Varela, E. (2019). Social Innovation in the non-profit organization framework: A review. Social Sciences, 8(8), 236.

https://doi.org/10.3390/socsci8080236 
Cáceres, E. (2014). El rol de las ONG en América Latina: Los desafios de un presente cambiante. Proyecto Regional "Mesa de Articulación y sus aliados del sur aumentan su capacidad de incidencia y diálogo con gobiernos y sector privado" 2013-2014. Retrieved from: http://mesadearticulacion.org/wp-content/uploads/2014/11/ROL-ONG-Latinoamerica.pdf

Carreras, I., Iglesias, M., \& Sureda, M. (2011). Transformar con éxito las ONG. El liderazgo del cambio, Programa ESADE. Liderazgo Social, Barcelona: Institut d'Innovació Social, ESADE, Barcelona.

Claver-Cortés, E., Zaragoza-Sáez, P.C., \& González-Illescas, M. (2018). Intellectual capital management: An approach to Organizational practices in Ecuador. Intangible Capital, 14(2), 270-285. https://doi.org/10.3926/ic.1158

Conejero, E. (2016). La innovación social desde el ámbito público: Conceptos, experiencias y obstáculos, Gestión y Análisis de Políticas Públicas. España, Madrid: Nueva Época. https://doi.org/10.24965/gapp.v0i15.10310

Consejería Presidencial para los Derechos Humanos. (2018). Colombia más allá del conflicto armado: Derechos humanos y tránsito a la paz. Bogotá: Presidencia de la Republica.

Dai, H., Lau, Y., \& Lee, K.H. (2019). Social Innovation, Value Penetration, and the Power of the Nonprofit Sector: Workers' Co-Operative Societies in Hong Kong. Nomprofit and Voluntary Sector Quarterly, 48(6), 1210-1228. https://doi.org/10.1177/0899764019863107

Damanpour, F. (2017). Organizational Innovation. Oxford, UK: Oxford Research Encyclopedia of Business and Management. https://doi.org/10.1093/acrefore/9780190224851.013.19

Damanpour, F., \& Aravind, D. (2011). Organizational Structure and Innovation Revisited: From Organic to Ambidextrous Structure. In M. Mumford (ed.), Handbook of Organizational Creativity. New York, USA: Elsevier. https://doi.org/10.1016/B978-0-12-374714-3.00019-7

Departamento Administrativo de Estadística - DANE. (2019). Gran encuesta integrada de hogares (GEIH) Mercado laboral. Bogotá: DANE. Retrieved from: https://www.dane.gov.co/index.php/estadisticas-por-tema/mercadolaboral/empleo-y-desempleo/geih-historicos

Dekoulou, P., \& Trivellas, P. (2017). Organizational structure, innovation performance and customer relationship value in the Greek advertising and media industry. Journal of Business \& Industrial Marketing, 32(3), 385-397. https://doi.org/10.1108/JBIM-07-2015-0135

Dedahanov, A.T., Rhee, C., \& Yoon, J. (2017). Organizational structure and innovation performance. Career Development International, 22(4), 334-350. https://doi.org/10.1108/CDI-12-2016-0234

do Adro, F.J.N., \& Leitão, J.C.C. (2020). Leadership and Organizational Innovation in the third sector: A systematic literature review. International Journal of Innovation Studies, 4(2), 51-67. https://doi.org/10.1016/j.ijis.2020.04.001

Dong, H., Yim, B., \& Zhang, J.J. (2020). Organizational structure, public-private relationships, and operational performance of large-scale stadiums: evidence from local governments in China. Sustainability, 12(19), 8002. https://doi.org/10.3390/su12198002

Doezema, T., Ludwig, D., Macnaghten, P., Shelley-Egan, C., \& Forsberg, E.M. (2019). Translation, transduction, and transformation: Expanding practices of responsibility across borders. Journal of Responsible Innovation, 6(3), 323-331. https://doi.org/10.1080/23299460.2019.1653155

Drucker, P. (2005). Managing the Nonprofit Organization: Principles and Practices. New York. USA: Harper.

European Commission (2004). European Innovation Scoreboard 2004. Brussels: European Commission.

Fuglsang, L., \& Sundbo, J. (2005). The Organizational Innovation system: Three modes. Journal of change Management, 5(3), 329-344. https://doi.org/10.1080/14697010500258056

Giannopoulou, C. (2011). Leading for Impact: Learning, Innovation, and Effectiveness in Greek Nonprofit Organizations. Athens, Greece: Department of Business Administration Athens University of Economics and Business. 
Godin, B. (2012). Social Innovation: Utopias of innovation from 1830 to the present. Project on the intellectual History of innovation, INRS, Montreal, Working paper No. 11.

Goldenberg, M., Kamoji, W., Orton, L., \& Williamson, M. (2009). Social Innovation in Canada: An update. Ottawa, Canadian: Policy Research Networks.

Greenhalgh, T., Robert, G., Macfarlane, F., Bate, P., \& Kyriakidou, O. (2004). Diffusion of innovations in service organizations: Systematic review and recommendations. Milbank Q, 82 (4): 581-629. https://doi.org/10.1111/j.0887-378X.2004.00325.x

Howaldt, J., \& Schwarz, M. (2010). Social Innovation: Concepts, research fields and international trends. Retrieved from: http://www.asprea.org/imagenes/IMO\%20Trendstudie Howaldt englisch Final\%20.pdf (Accessed: July 13 $3^{\text {th }}$ 2016).

Hull, C.E., \& Lio, B.H. (2006). Innovation in Non-Profit and for-profit organizations: Visionary, strategic, and financial considerations. Journal of Change Management, 6(1), 53-65. https://doi.org/10.1080/14697010500523418

Jaskyte, K. (2018). Board attributes and processes, board effectiveness, and Organizational Innovation: Evidence from nonprofit organizations. Voluntas, 29(5), 1098-1111. https://doi.org/10.1007/s11266-017-9945-y

Jevanesan, T., Antony, J., Rodgers, B., \& Prashar, A. (2019). Applications of continuous improvement methodologies in the voluntary sector: A systematic literature review. Total Quality Management and Business Excellence, 32(3-4), 431-447. https://doi.org/10.1080/14783363.2019.1588723

Klassen, M., Dobni, C.B., \& Neufeldt, V. (2020). Innovation orientation and performance in the not-for-profit sector. International Journal of Business Innovation and Research, 23(4), 540-560. https://doi.org/10.1504/IJBIR.2020.111769

Laurett, R., \& Ferreira, J. J. (2018). Strategy in nonprofit organizations: A systematic literature review and agenda for future research. Voluntas: International Journal of Voluntary and Nonprofit Organizations, 29(5), 881-897. https://doi.org/10.1007/s11266-017-9933-2

Lee, R.P., Ginn, G.O., \& Naylor, G. (2009). The impact of network and environmental factors on service innovativeness. Journal of Services Marketing, 23(6), 397-406. https://doi.org/10.1108/08876040910988183

Levésque, B. (2012). Social Innovation and Governance in public management Systems: Limits of NPM and search for alternatives? Quebec, Canadá: Centre de Recherche sur les Innovations Sociales (CRISES).

McNutt, J., Guo, C., Goldkind, L., \& An, S. (2018). Technology in nonprofit organizations and voluntary action. Voluntaristics Review, 3(1), 1-63. https://doi.org/10.1163/24054933-12340020

Miranda, M.Q., Farias, J.S., de Araújo Schwartz, C., \& de Almeida, J.P.L. (2016). Technology adoption in diffusion of innovations perspective: introduction of an ERP system in a non-profit organization. RAI Revista de Administração e Inovação, 13(1), 48-57. https://doi.org/10.1016/j.rai.2016.02.002

Moore, M.-L., \& Westley, F.R. (2011). Surmountable chasms: Networks and Social Innovation for resilient systems. Ecology and Society, 16, 5. Retrieved from: http://www.ecologyandsociety.org/vol16/iss1/art5 https://doi.org/10.5751/ES-03812-160105

Morente, F., \& Ferràs-Hernández, X. (2017). Innovation management from the inside: An approach from attention and everyday praxis. Intangible Capital, 13(3), 640-667. https://doi.org/10.3926/ic.1004

Moulaert, F., MacCallum, D., Mehmood, A., \& Hamdouch, A. (2013) (Ed.). The International Handbook on Social Innovation: Collective Action, Social Learning and Transdisciplinary Research. Cheltenham, UK, Northampton, MA, USA: Edward Elgar.

Mulgan, G., Ali, R., Halkett, R., \& Sanders, B. (2007). In and out of sync: The challenge of growing Social Innovations (Research report). London, England: National Endowment for Science, Technology, and the Arts. Retrieved from: http://www.socialinnovationexchange.org/node/238 
Mumford, M.D. (2002). Social Innovation: Ten cases from Benjamin Franklin. Creativity Research Journal, 14(2), 253-266. https://doi.org/10.1207/S15326934CRJ1402_11

Murray, R., Caulier, J., \& Mulgan, G. (2010). The open book of Social Innovation. London: The Young Foundation. Retrieved from: http://www.kwasnicki.prawo.uni.wroc.pl/pliki/Social Innovator 020310.pdf

Netting, F. E., \& Nelson, H.W. (2020). Managing disaster preparation amid conflicts of interest: A teaching/learning case study. Human Service Organizations: Management, Leadership \& Governance, 44(2), 187-197. https://doi.org/10.1080/23303131.2019.1707733

OECD/Eurostat. (2018). Oslo Manual: Guidelines for Collecting, Reporting and Using Data on Innovation, 4th Edition, The Measurement of Scientific, Technological and Innovation Activities, OECD Publishing, Paris/Eurostat, Luxembourg. https://doi.org/10.1787/9789264304604-en

Oliveira, M., Sousa, M., Silva, R., \& Santos, T. (2021). Strategy and Human Resources Management in Non-Profit Organizations: Its Interaction with Open Innovation. Journal of Open Innovation: Technology, Market, and Complexity, 7(1), 75. https://doi.org/10.3390/joitmc7010075

Packard, T. (2010). Staff Perceptions of Variables Affecting Performance in Human Service Organizations. Nomprofit and Voluntary Sector Quarterly, 39(6), 971-990. https://doi.org/10.1177/0899764009342896

Park, S., Kim, J., Park, J., \& Lim, D.H. (2018). Work engagement in nonprofit organizations: A conceptual model. Human Resource Development Review, 17(1), 5-33. https://doi.org/10.1177/1534484317750993

Rathi, D., \& Given, L.M. (2016, November). Use of Technology in Non-Profit Organizations (NPOs) for Knowledge Management. In Proceedings of the Annual Conference of CAIS/Actes du congresannuel de l'ACSI. https://doi.org/10.29173/cais960

Rodríguez, E., Carreras, I., \& Sureda, M. (2012). Innovar para el cambio social. De la idea a la acción. Madrid: ESADE.

RICYT Red Iberoamericana de Ciencia y Tecnología. (2004). Manual de Bogotá: Normalización de Indicadores de Innovación Tecnológica en América Latina y el Caribe. Bogotá: Red Iberoamericana de Ciencia y Tecnología (RICYT), Organización de Estados Americanos (OEA), Programa CYTED.

Shilbury, D., \& Moore, K.A. (2006). A Study of Organizational Effectiveness for National Olympic Sporting Organizations. Nonprofit and Voluntary Sector Quarterly, 35(1), 5-38. https://doi.org/10.1177/0899764005279512

Shin, E.J., Kang, H.G., \& Bae, K. (2020). A study on the sustainable development of NPOs with blockchain technology. Sustainability, 12(15), 6158. https://doi.org/10.3390/su12156158

Schreiner, E., Trent, S.B., Prange, K.A., \& Allen, J.A. (2018). Leading volunteers: Investigating volunteers' perceptions of leaders' behavior and gender. Nonprofit Management and Leadership, 29(2), 241-260. https://doi.org/10.1002/nml.21331

Taylor, R., \& Arundel, A. (2019). Organizational pathways for Social Innovation and societal impacts in disability nonprofits. VOLUNTAS: International Journal of Voluntary and Nonprofit Organizations, 31(5), 995-1012. https://doi.org/10.1007/s11266-019-00113-8

Tran, L. (2019). International NGO Centralization and Leader-Perceived Effectiveness. Nomprofit and Voluntary Sector Quarterly, 49(1), 134-159. https://doi.org/10.1177/0899764019861741

Urionabarrenechea, M.L.M., Lage, J.C., \&Arrizabalaga, C.E. (2015). Gestionar con calidad las entidades sin ánimo de lucro: Hacia una eficacia, eficiencia y economía en la rendición de cuentas. Revista de Estudios Empresariales, 1, 28-57. Retrieved from: https://revistaselectronicas.ujaen.es/index.php/REE/article/view/2205/2042

Vázquez-Maguirre, M., \& Portales, L. (2018). Profits and purpose: Organizational tensions in indigenous social enterprises. Intangible Capital, 14(4), 604-618. https://doi.org/10.3926/ic.1208 
Verschuere, B., Beddeleem, E., \& Verlet, D. (2014). Determinants of innovative behaviour in Flemish nonprofit organizations: An empirical research. Public Management Review, 16(2), 173.

https://doi.org/10.1080/14719037.2012.757347

Waddell, S. (2011). The Global Compact: An organizational innovation to realize UN Principles. Issued in November. New York. United Nations Global Compact.

Westley, F., \& Antadze, N. (2010). Making a difference: Strategies for scaling Social Innovation for greater impact. The Public Sector Innovation Journal, 15(2), article 2. https://doi.org/10.1108/01437730710739675

Westley, F., Antadze, N., Riddell, D.J., Robinson, K., \& Geobey, S. (2014). Five configurations for scaling up Social Innovation: Case examples of nonprofit organizations from Canada. The Journal of Applied Behavioral Science, 50(3), 234-260. https://doi.org/10.1177/0021886314532945

Winand, M., \& Anagnostopoulos, C. (2017). Get ready to innovate! Staff's disposition to implement service innovation in non-profit sport organisations. International Journal of Sport Policy and Politics, 9(4), 579-595 https://doi.org/10.1080/19406940.2017.1308418

Winand, M., Scheerder, J., Vos, S., Zintz, T., \& Hoeber, L. (2011). Service innovation in Non-Profit sports organizations. 11th Conference, Euram 2011. European Academy of Management. Retrieved from: https://www.researchgate.net/publication/289893579 Service innovation in NonProfit sport organizations (Accessed April 13, 2018).

Wit, A. de, \& Mensink, W. (2019). Beyond service production: Volunteering for Social Innovation. Nonprofit and Voluntary Sector Quarterly, 48(2_suppl), 52S-71S. https://doi.org/10.1177/0899764017734651

Zhang, Y., Khan, U., Lee, S., \& Salik, M. (2019). The influence of management innovation and technological innovation on organization performance. A mediating role of sustainability. Sustainability, 11(2), 495.

https://doi.org/10.3390/su11020495

Article's contents are provided on an Attribution-Non Commercial 4.0 Creative commons International License. Readers are allowed to copy, distribute and communicate article's contents, provided the author's and Intangible Capital's names are included. It must not be used for commercial purposes. To see the complete license contents, please visit https://creativecommons.org/licenses/by-nc/4.0/. 